مراجعة كتاب وقراءة نقدية لـ: - مل

كتاب الدرس الصرفي في"شرح على السلك والعنوان ومقام اللؤلؤ منه والعقيان" المنسوب إلى ابن عصفور

Morphological Lesson in Ibn 'ușfūr work entitled: "al-Silk wa al-' unwā wa Maqām al-Lu'lu' Minhu wa al- 'uqyān'

Penajaran Saraf di dalam Karangan Ibn Usfur Berjudul: "al-Silk wa al- unwā wa Maqām al-Lu'lu' Minhu wa al- 'uqyān"

صباح عبد الله مُمَّمَ بافضل

أولاً: تعريف موجز بالكتاب

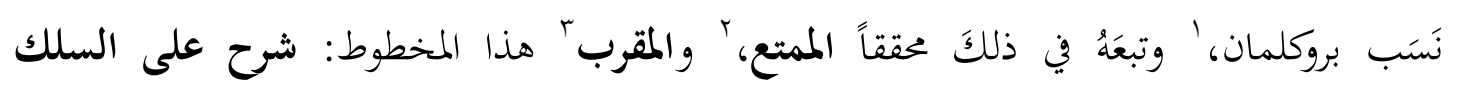

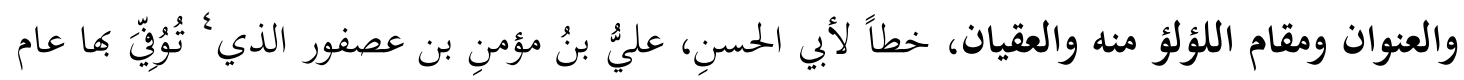

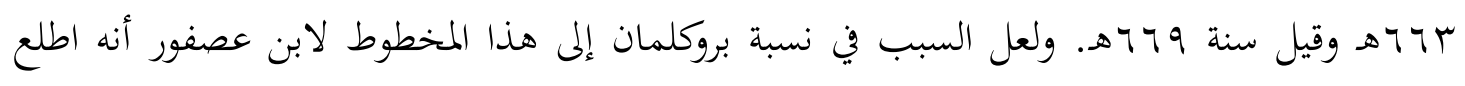

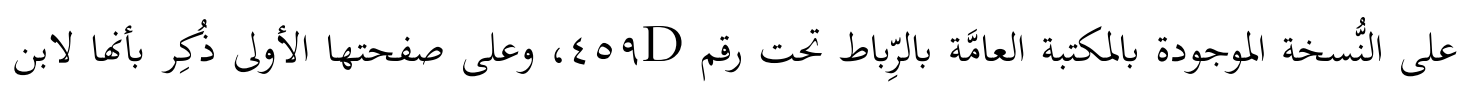

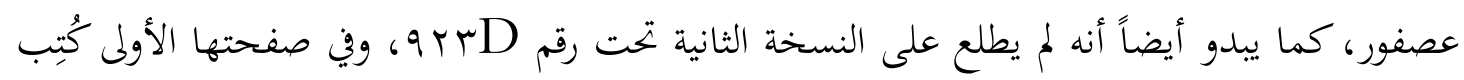
أها لابن خروف.

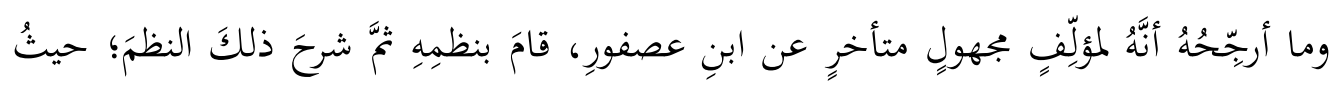

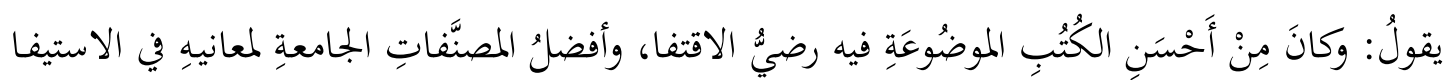

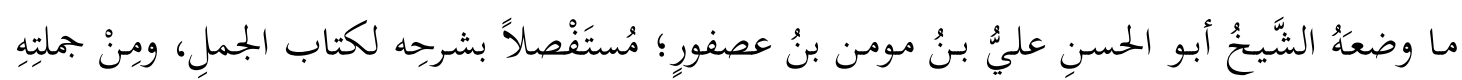

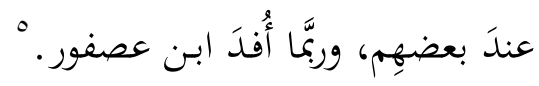

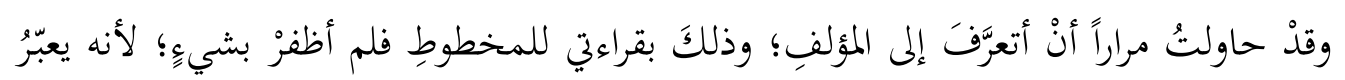

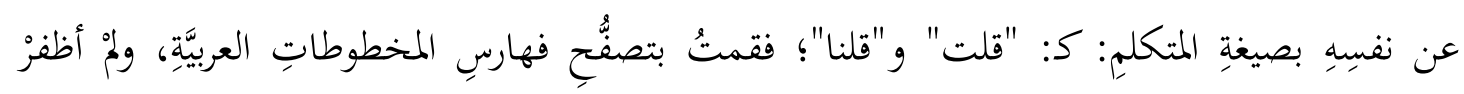


مراجعة كتاب وقراءة نقدية ل: كتاب الدرس الصرفي في" شرح السلك والعنوان ومقام الؤلؤة منه والعقيان" المنسوب إلى ابن عصفور

بنتيجةٍة، فشرعت في مراسلة مركزي الملك فيصل للمخطوطات، وإحياء التراث الإسلامي؛ لكني لم

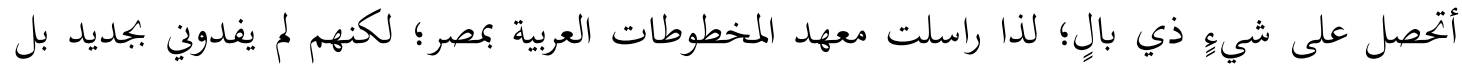

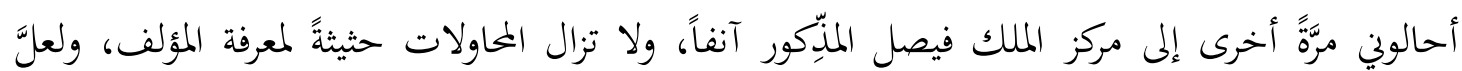
الأيام تكشف لي عن ذلك.

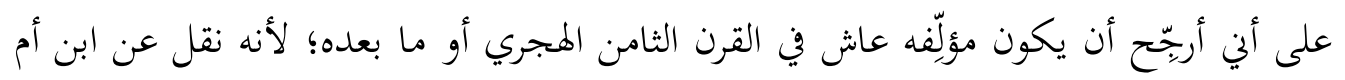

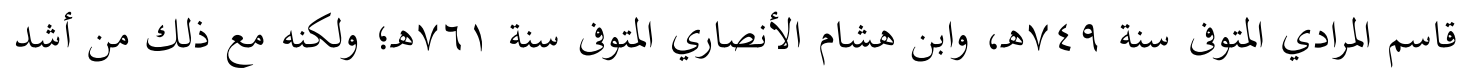

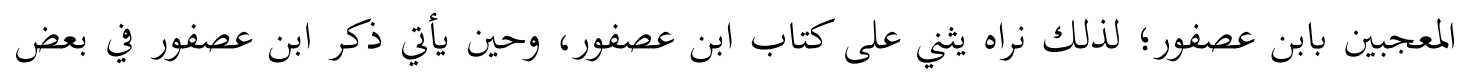

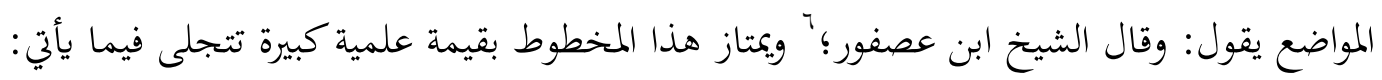

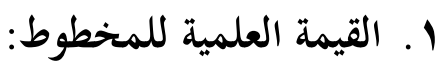

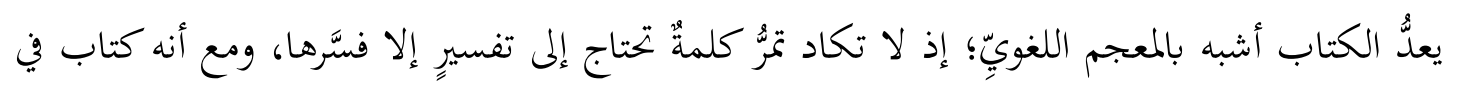

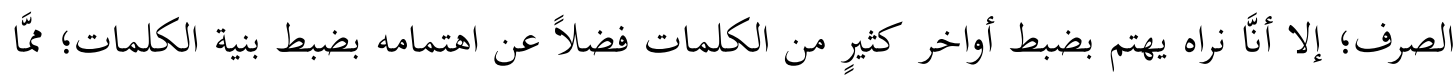

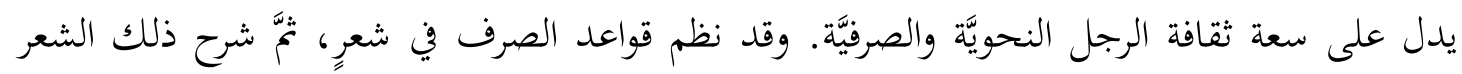

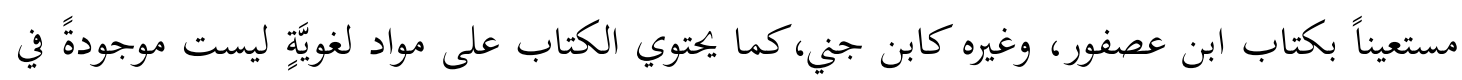

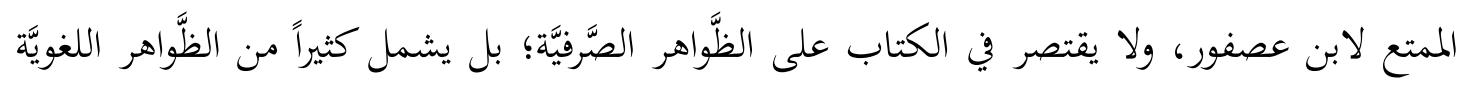
المتنِِعة: أ. ففي مجال النحو نجده يعرب غالب كلمات النَّظم بعد انتهائه من مناقشته الصرفيَّة، ومن ذلك:

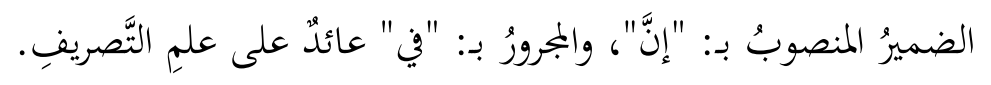

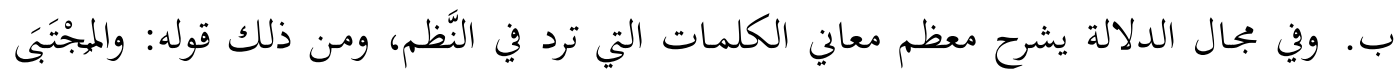

$$
\text { هوَ: المُخْتَارُ. }
$$

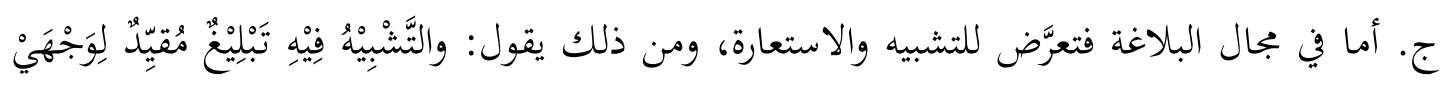

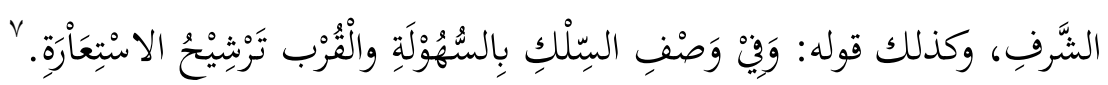

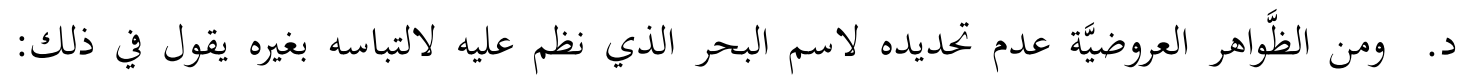

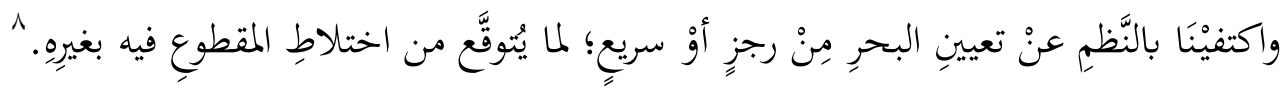

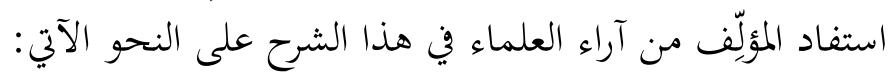

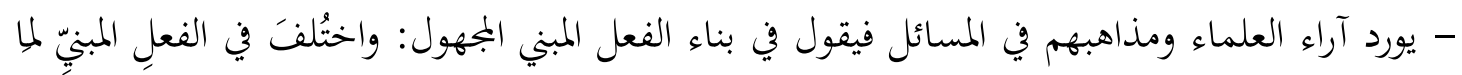

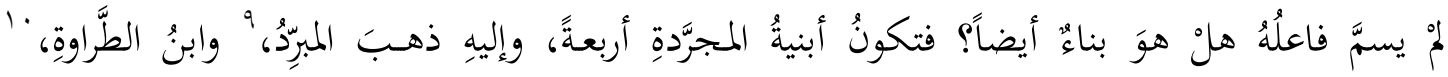




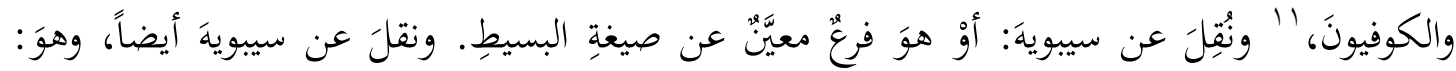
أظهرُ القولين.

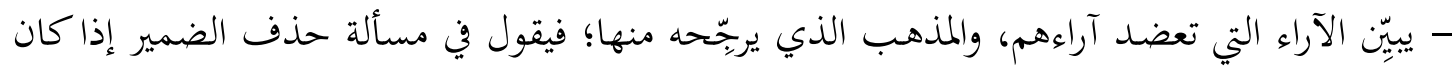

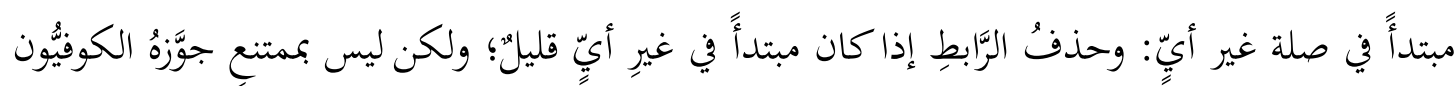

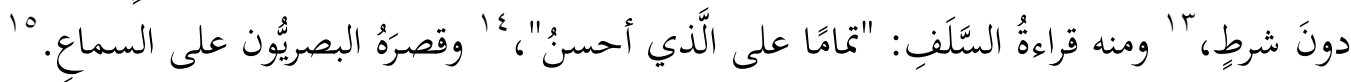

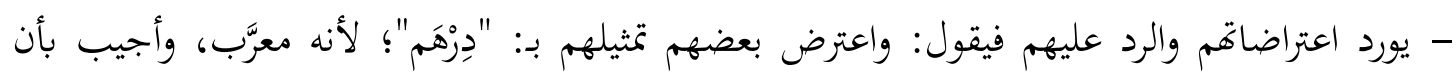

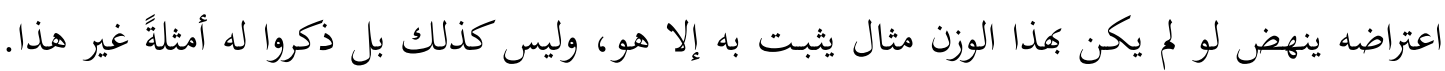
انظر المرادي.

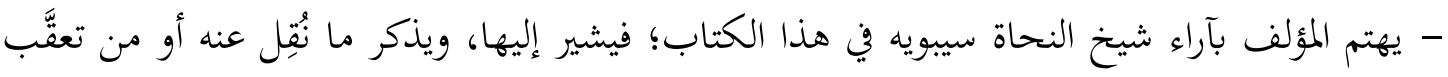

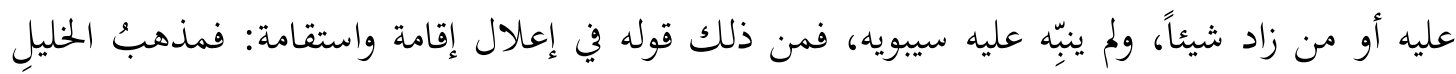

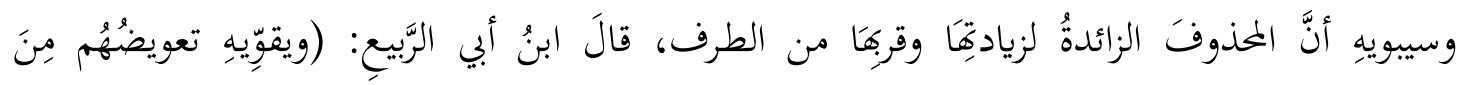

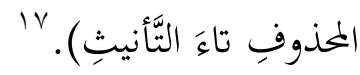
- يورد المؤلف في الكتاب آراء علماء لم تُعرف آراؤهم إلا من خلال كتب علماء آخرين ذكروها في

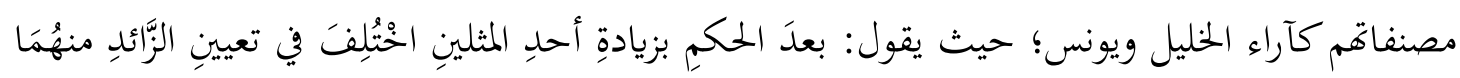

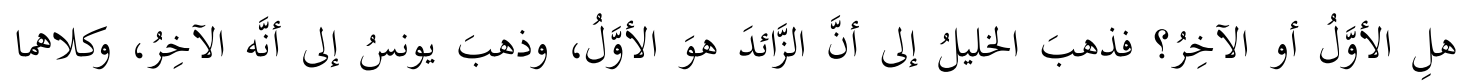

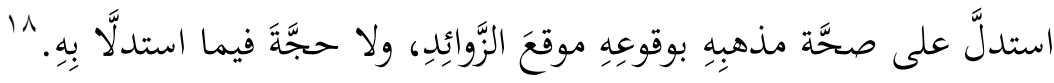

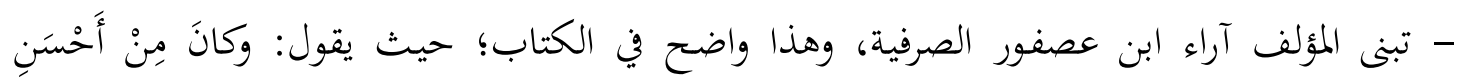

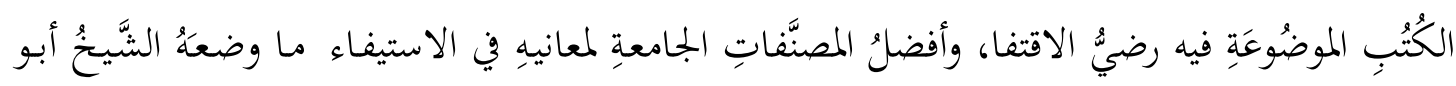

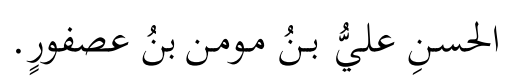
لذا قام المؤلف في هذا الكتاب بنظم تصريفه ثم شرح ذلك النظ النظم؛ فتراه لا يغفل آراءه بل يذكرها

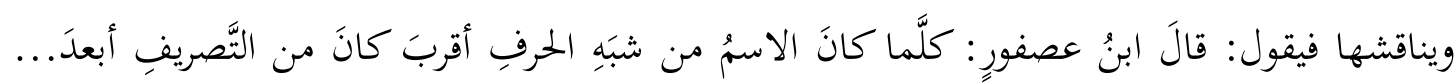

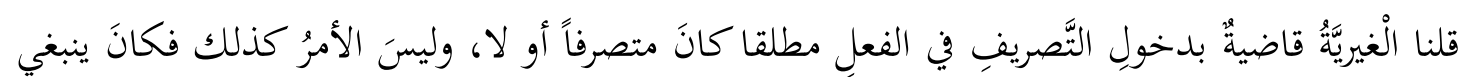
التقييدُ بالتَّصرُّفِ. 19 - يستعمل المؤلف الأصول النحوية لتعضيد رأيه، ومن تلك الأصول: القياس؛ إذ أبطل الاشتقاق الكبير

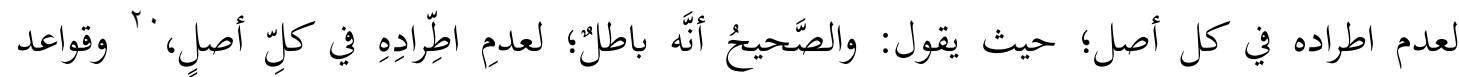

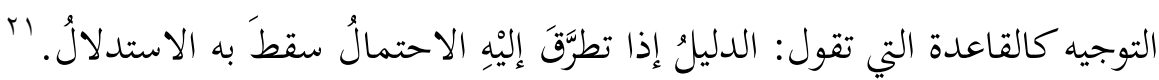

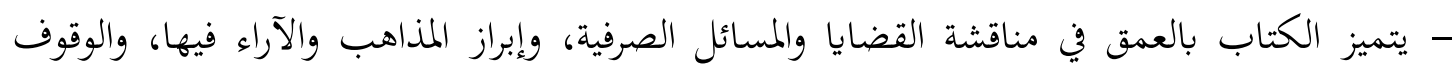

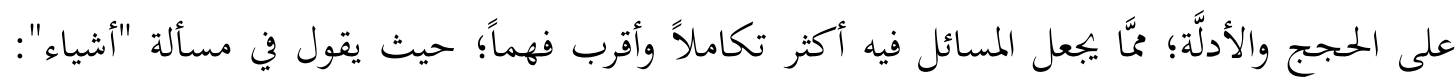

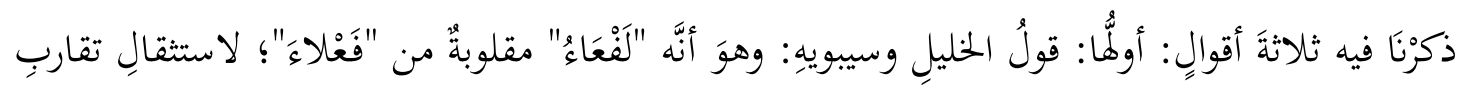


مراجعة كتاب وقراءة نقدية ل: كتاب الدرس الصريف في" شرح السلك والعنوان ومقام الؤلؤة منه والعقيان" المنسوب إلى ابن عصفور

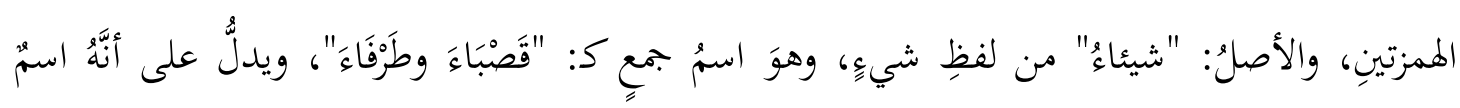

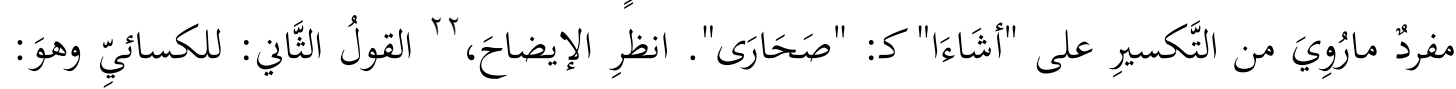

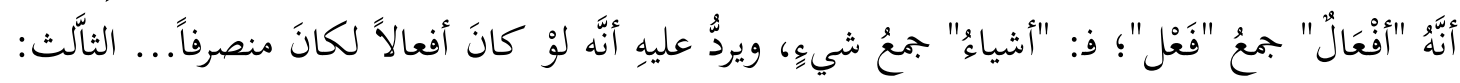

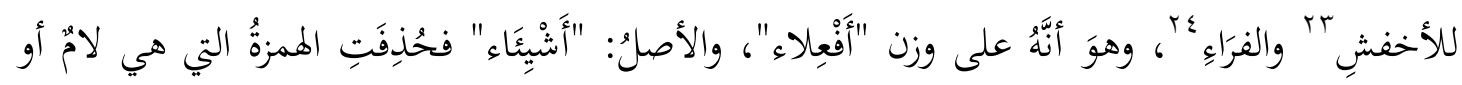

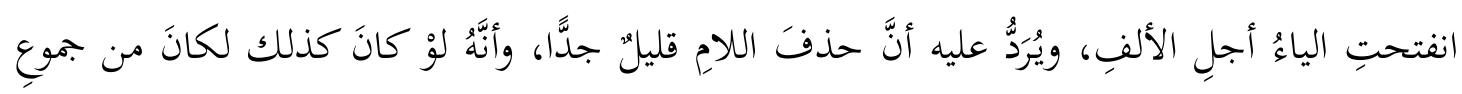

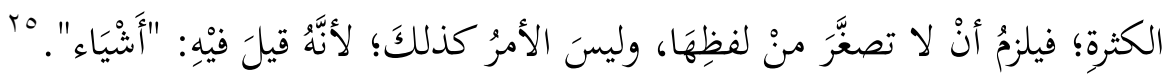

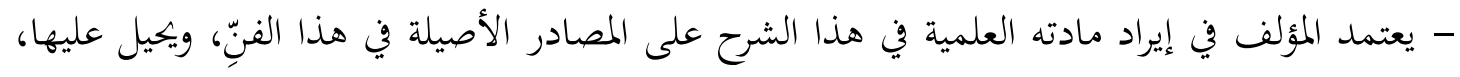

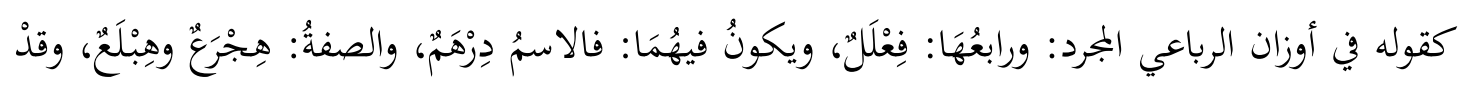

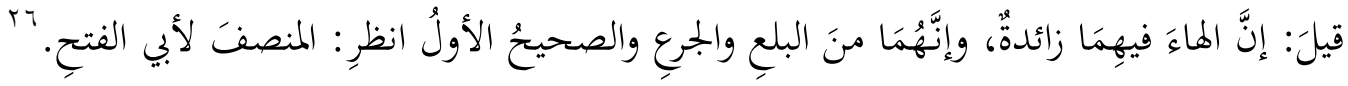
ثانياً: المصادر التي استقى منها مادته العلميَّة

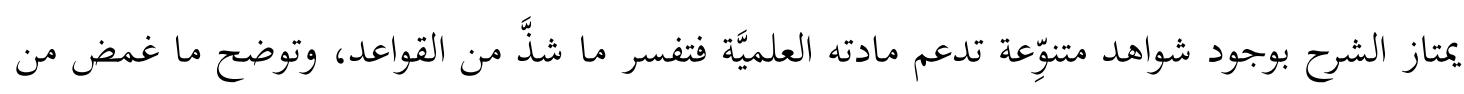
المفردات.

1. فمثنال إيراده لمصدر الثَّاهدَ القرآينَّ:

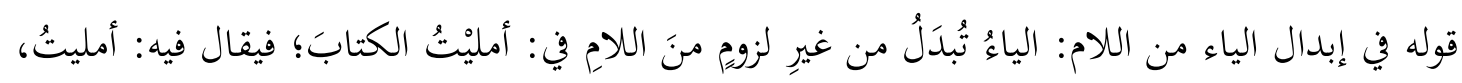

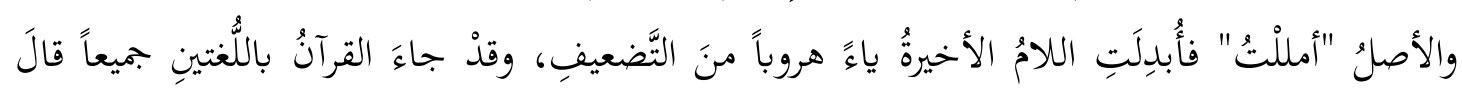

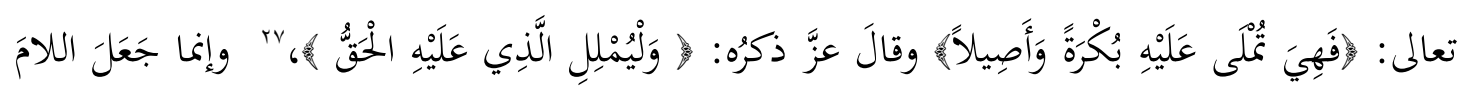

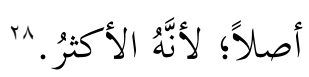

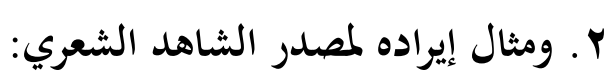

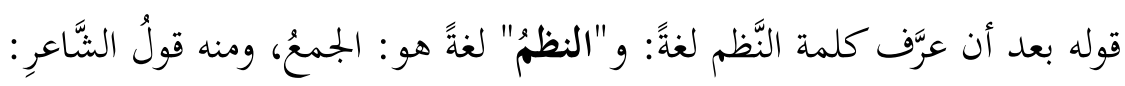

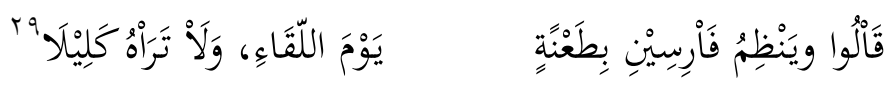

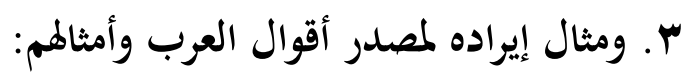

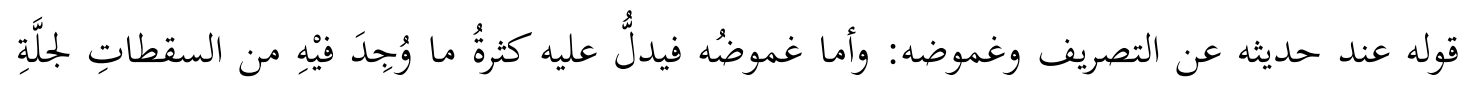

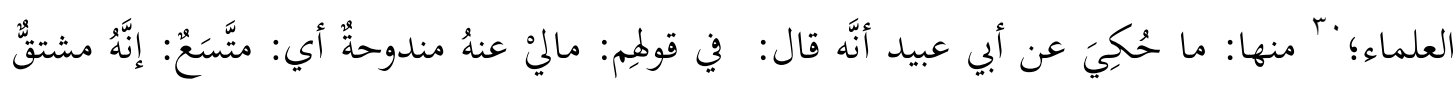

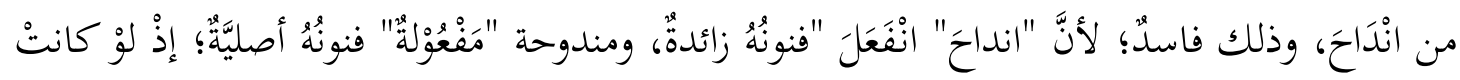

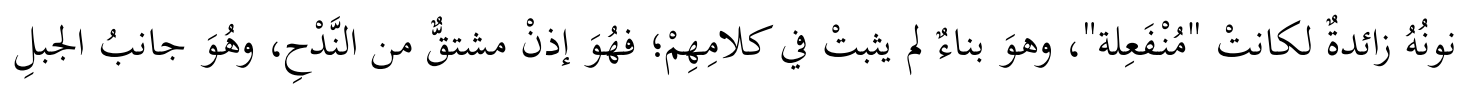

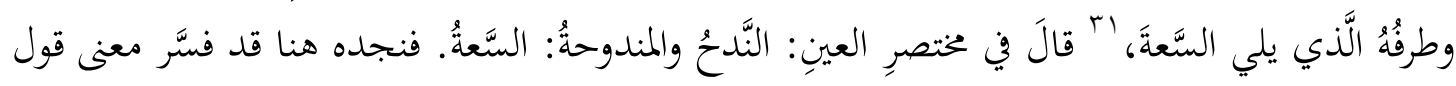
العرب، وأورد أقوال العلماء في ذلك. 
ثالثاً: منهج المؤلف في الكتاب 1. يمتاز الشرح بحسن التقسيم والتفصيل بعد الإجمال، وربط اللاحق بالسابق بالإشارة إليه؛ ومن ذلك:

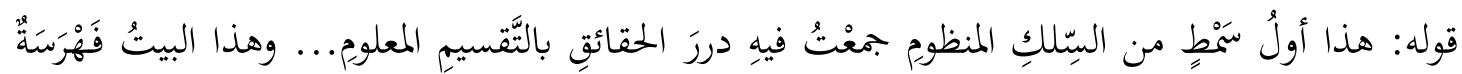

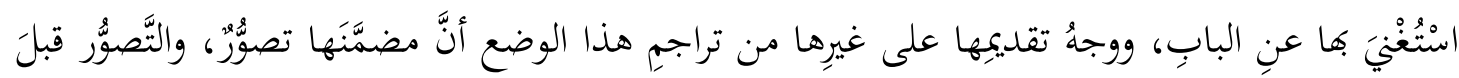

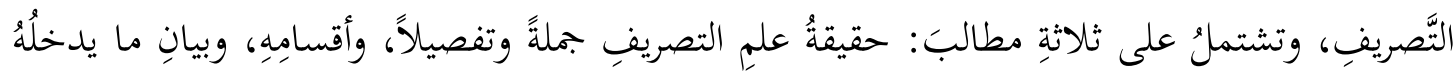
النَّصريفُ وما لا يدخلُه. r. يعرب المؤلف معظم النَّم الذي نظمه، ويشرح الكلمات الغامضة فيه، ومن أمثلة ذلك: ما ذكره

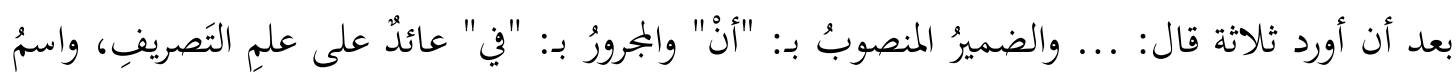

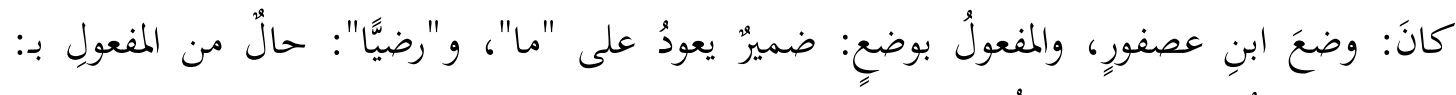

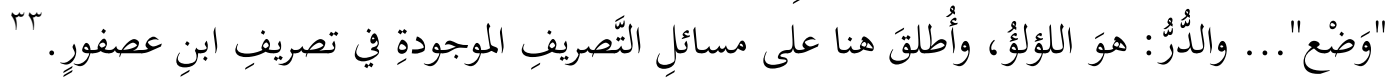

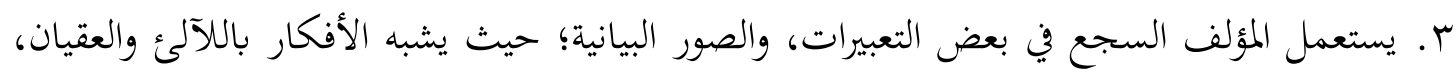

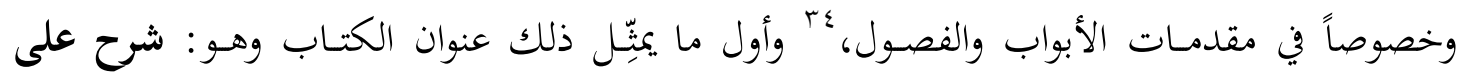
السلك والعنوان ومقام اللؤلؤ منه والعقيان، ويذكر المؤلف في شرحه بعض الاستعارات؛ فيقول:

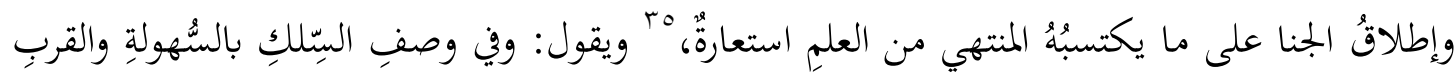
ترشيح الاستعارة.

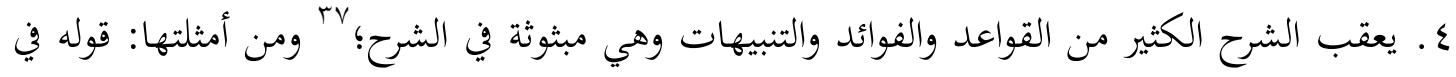

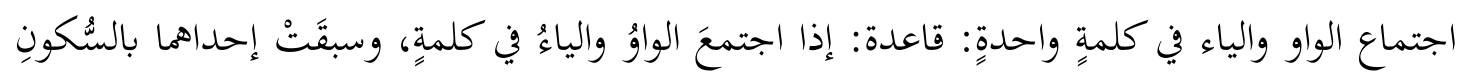

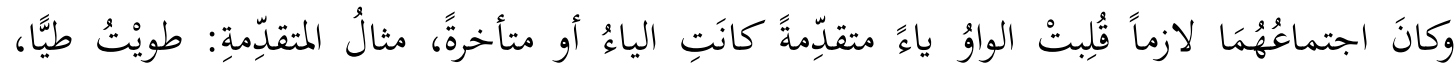

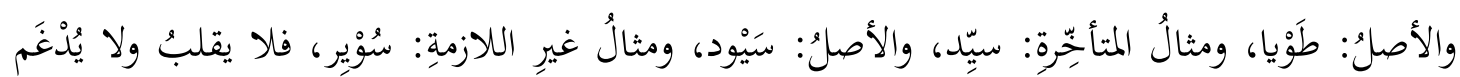
لعدمِ وجودِ الواوِ.

ه. يعرض المؤلف مادته العلمية شارحاً وموضحاً ومبيّناً؛ مستعملا لذلك أساليب متنوعة، منها:

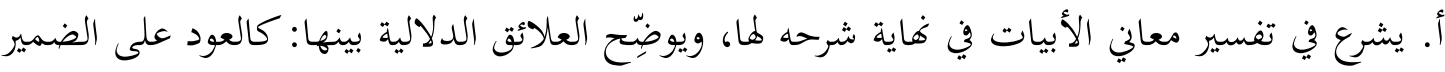

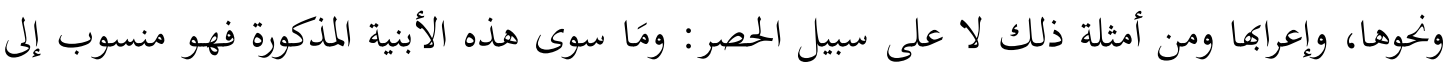

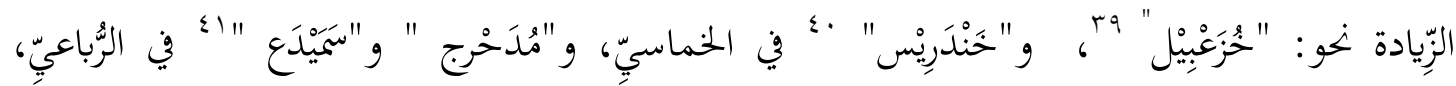

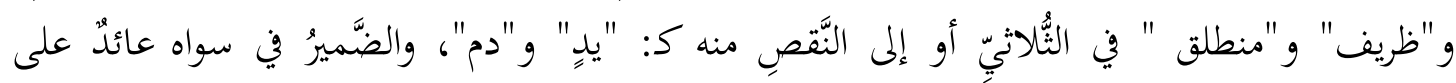

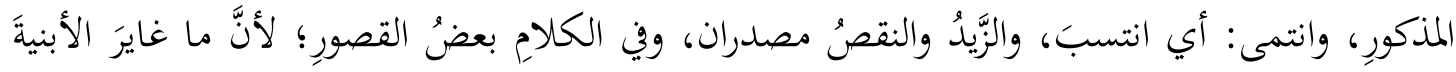

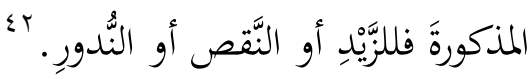


مراجعة كتاب وقراءة نقدية ل: كتاب الدرس الصريف في" شرح السلك والعنوان ومقام الؤلؤة منه والعقيان" المنسوب إلى ابن عصفور

ب. يفترض المؤلف أحياناً شخصاً يعترض ويجيب عليه، ومن أمثلة ذلك: وأمَّا قولُمهم: مَا أحفلُ بفلانٍ

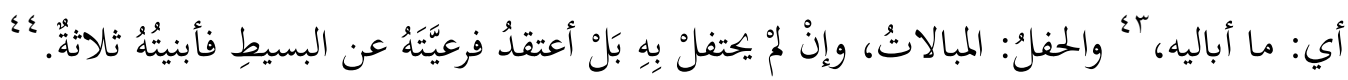

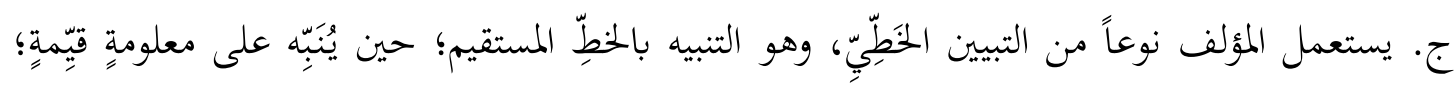

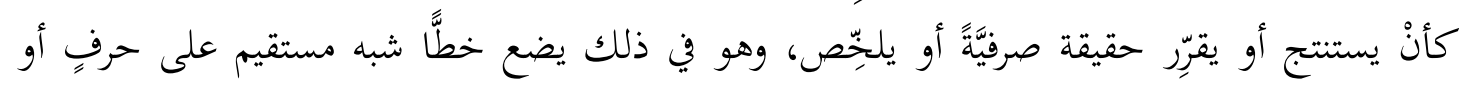

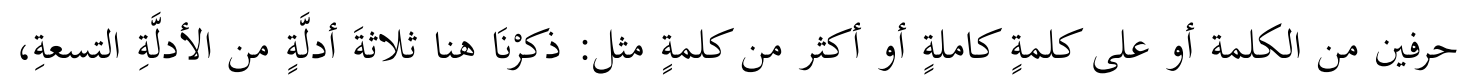

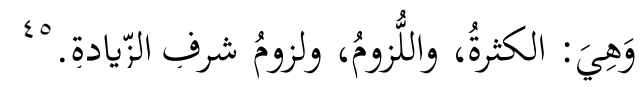

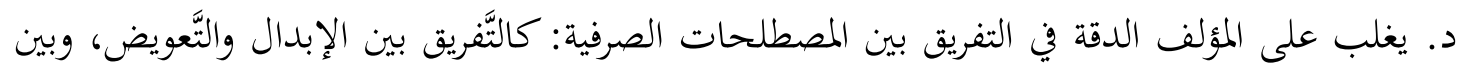

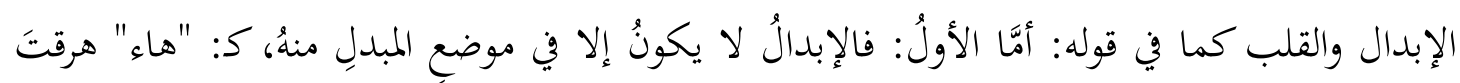

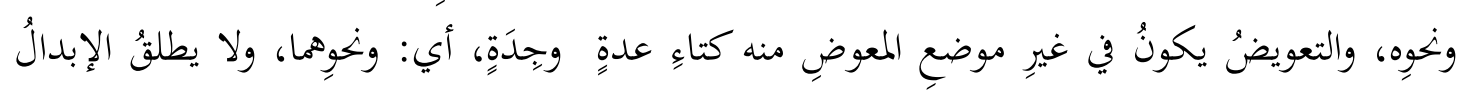

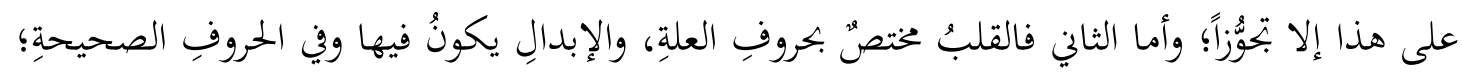

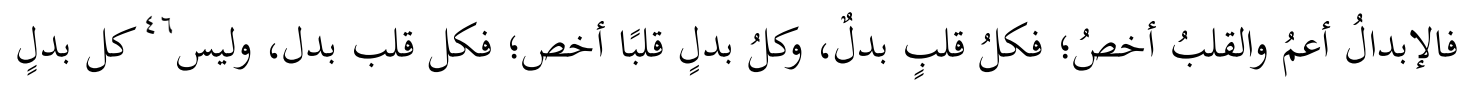
قلباً.

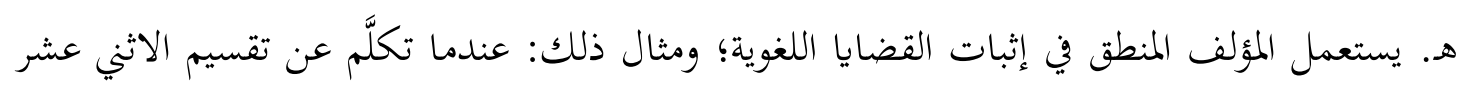

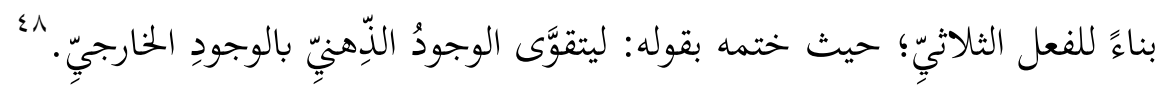

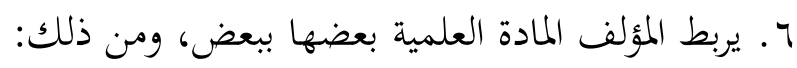

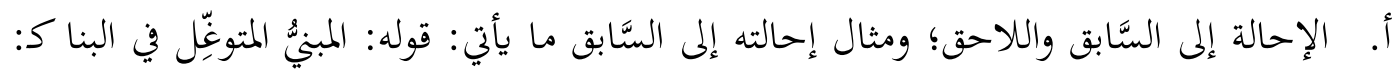

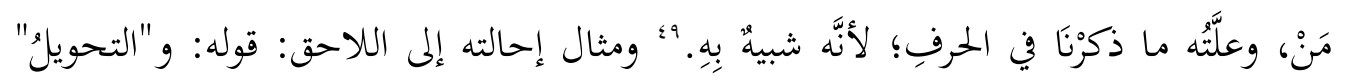

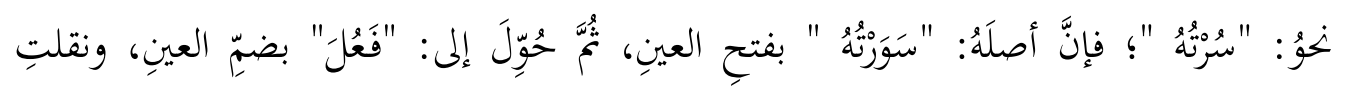

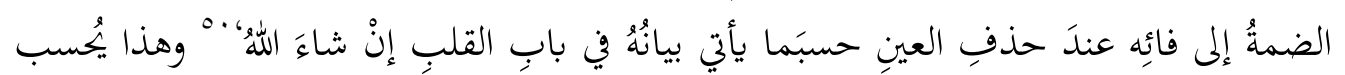
له؛ تفادياً للتكرار.

ب. الإحالة إلى المطوَلات؛ فمن مآثر الكتاب أنه يأتي بالقواعد الصَّرفيَّة مجملةً مصفَّةًَ، ويحيل على المطوَّلات لمن أراد مزيداً من الشَّرح والتَّفصيل؛ ومن ذلك: حين تحدَّث عن أبنية الرباعي الأصلي والمزيد؛

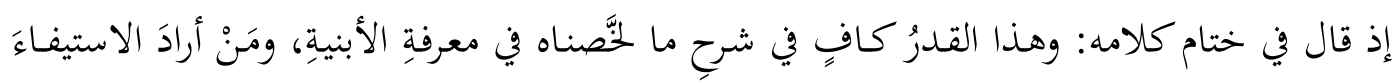
فعليه بالمطوَّلاتِ.

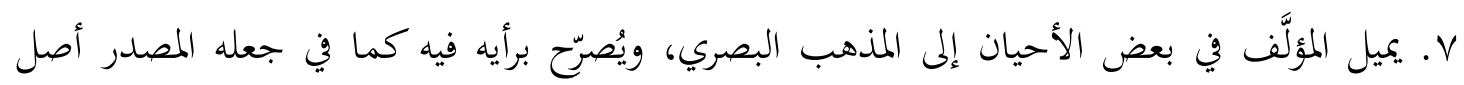

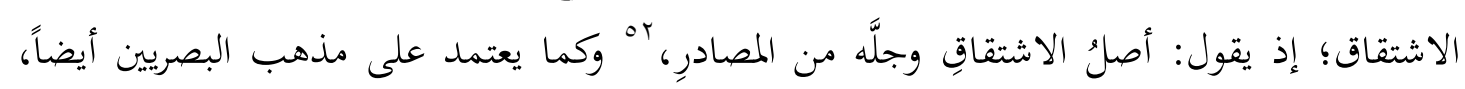




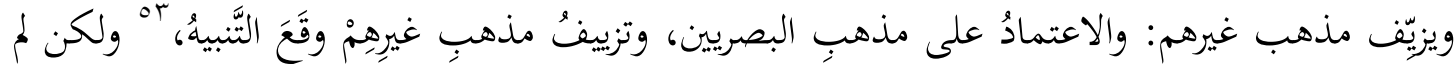

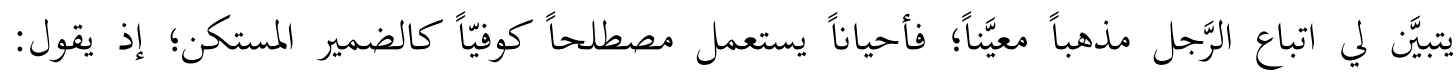

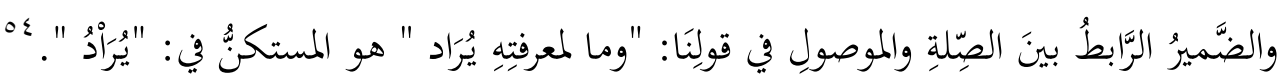

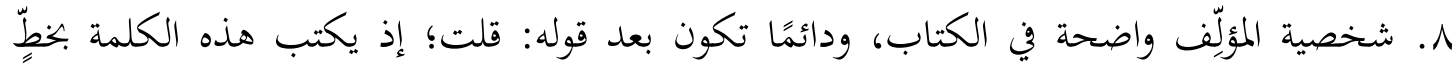

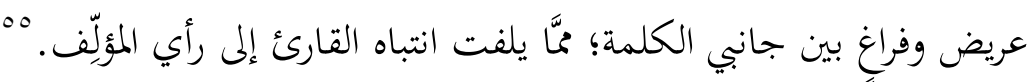

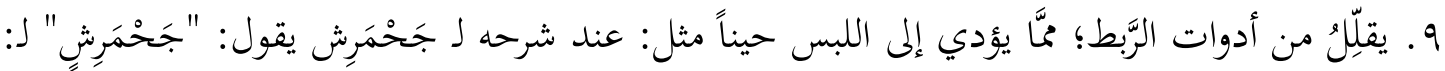

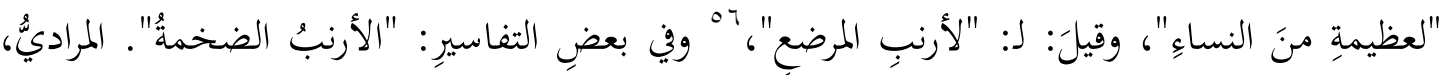

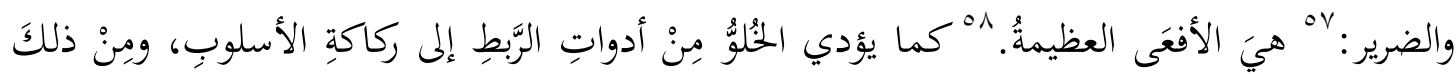

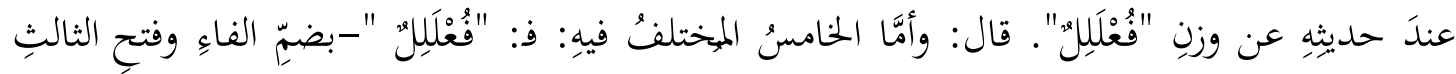

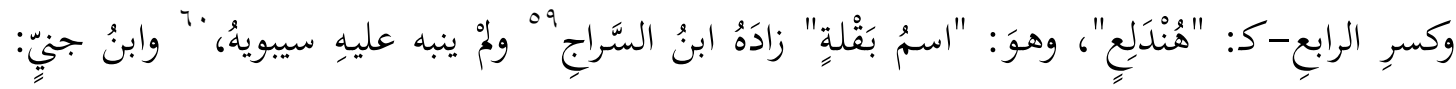

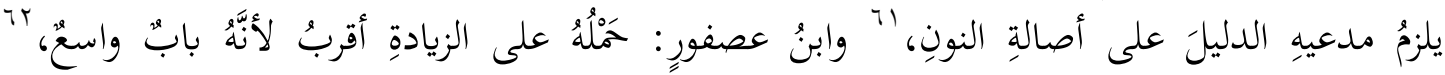

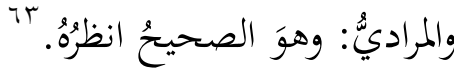

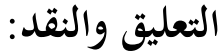

بعد هذه الرحلة الممتعة مع الكتاب خلص البحث إلى بجموعة من النتائج أجملها فيما يأني:

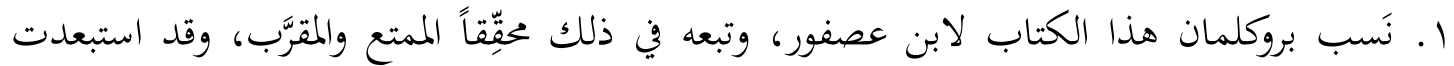

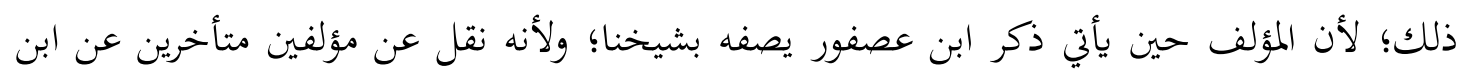

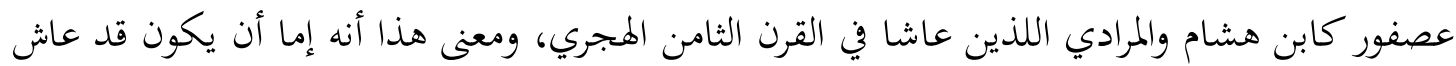
في أواخر القرن الثامن أو القرن التاسع. r. هناك نسختان للمخطوط: الأولى رمزت لها بالرمز (أ) نسب فيها الناسخ الكتاب لابن عصفور، والنسخة الثانية رمزت لها بالرمز ب، ونسب فيها الكتاب لابن خروف. على الرغم من أن النسختين

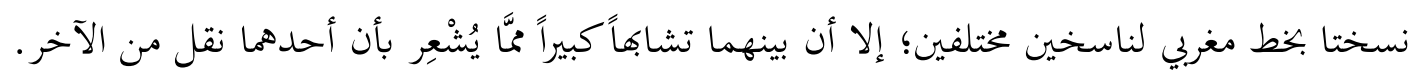

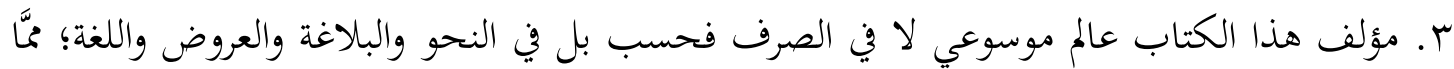

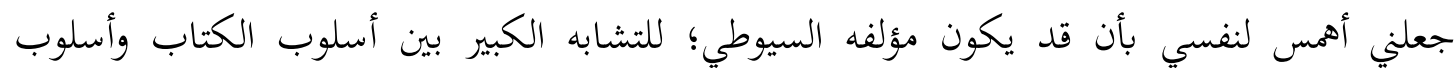

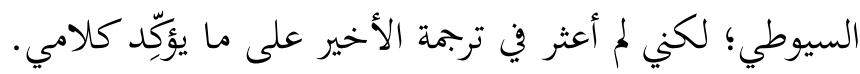
ع. مؤلف هذا الكتاب معجب بابن عصفور فلا يكاد ينقل عنه إلا يقول شيخنا أو الشيخ. ه. للكتاب قيمة علمية كبيرة؛ فهو ليس كتابًا في الصرف فحسب؛ بل يضم في ثناياه معجمًا لغويًاً

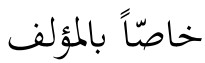


مراجعة كتاب وقراءة نقدية ل: كتاب الدرس الصريف في" شرح السلك والعنوان ومقام الؤلؤة منه والعقيان" المنسوب إلى ابن عصفور

7. أثبت المؤلف في كتابه نزعته البصرية، وقد صرَّح بذلك في كتابه. وكما كان ميالاً إلى النزعة البصرية؛ فكان أمراً طبعيّاً أن يهتم بنقل آراء شيخ النحاة سيبويه؛ لذلك نراه يكثر من النقل عنه. V. كان يعتمد في كتابه على الأصول النحوية: كالسماع والقياس والمنطق.

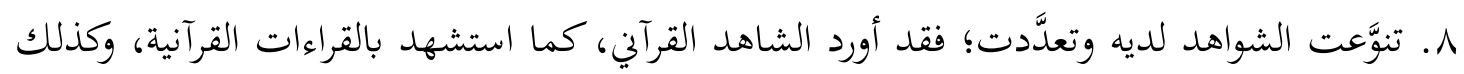
اعتمد على الشاهد الشعري، وأقوال العرب وأمثالهم. 9. يمتاز المؤلف في منهجه بالشرح وحسن التقسيم، والتفصيل بعد الإجمال، وربط اللاحق بالسابق والعكس مبدأ الإحالة. • ا ـ يميل المؤلف إلى استعمال السجع في كثير من تعبيراته وأكبر برهان لذلك عنوان الكتاب، مّّا جعلني أتوهم أن الكتاب للسيوطي؛ لأن عناوين كتبه غالباً ما تكون مسجوعة، وبالإضافة إلى ذلك فإنه يهتم بإيراد الصور البيانية. 1 ا ـ وأخيراً فإن شخصية المؤلف واضحة، وتظهر في تأييده لأراء بعضهم أو ردها أو ترجيح بعضها على بعض أو انفراده برأي. وإنَّ الرَّجل متمكِّنُ من علم الصرف حتى النخاع ويتَّضح ذلك عند معالجته للمواضيع؛ حيث يعالجها بصور كلية.

\section{هوامش البحث:}

' بروكلمان، كارل، تاريخ الأدب العربي، طr، نقله إلى العببة: رمضان عبد التواب، وراجعها: السيد يعقوب بكر، (القاهرة: دار المعارف

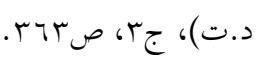

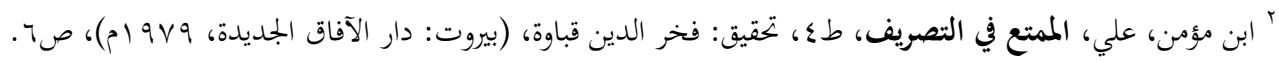

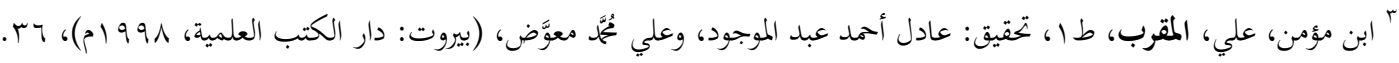

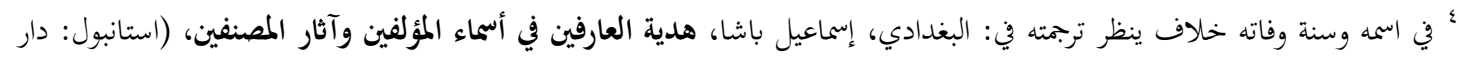

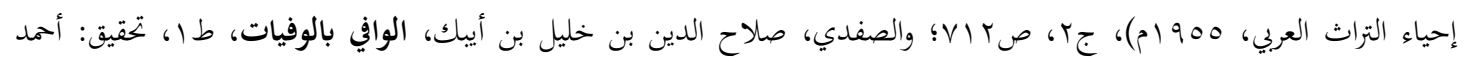

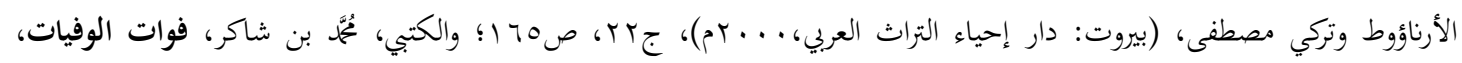

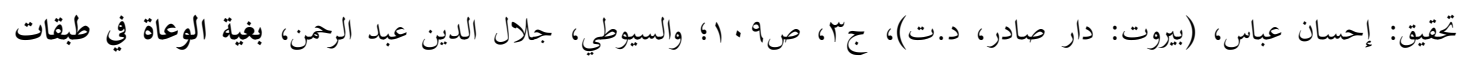

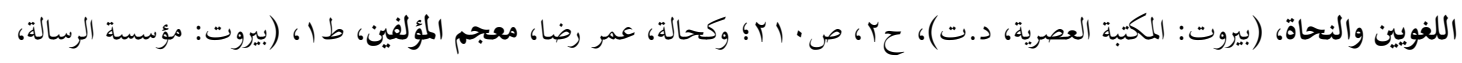

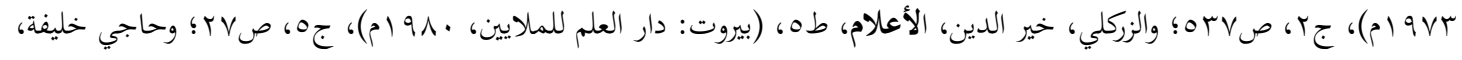

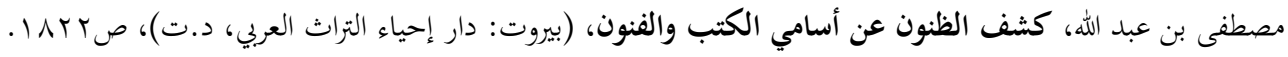

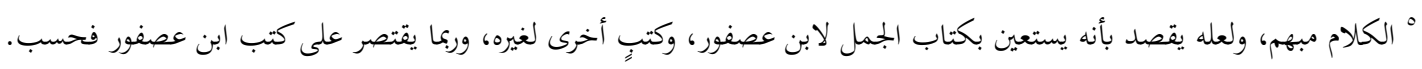

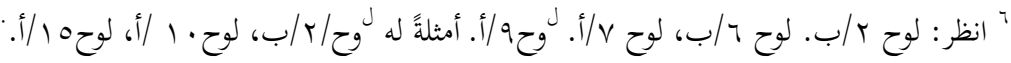

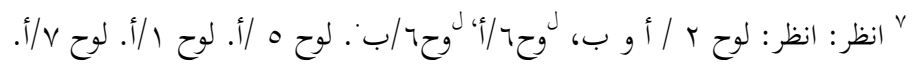
^ انظر : لوح / ابظر : انظر: لوح / من المخطوط. 


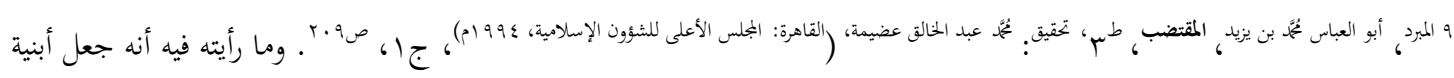

الفعل ثلاثة لا أربعة.

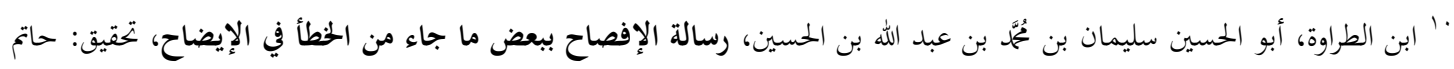

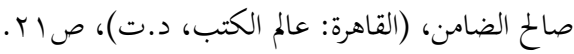

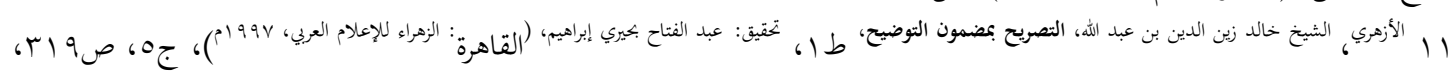
وهذا رأي المازني؛ انظر: ابن جني، أبو الفتح عثمان، المنصف، طا، تحقيق: إبراهيم مصطفى وعبد الله أمين، (القاهرة: إحياء التراث القديم

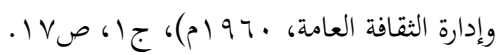

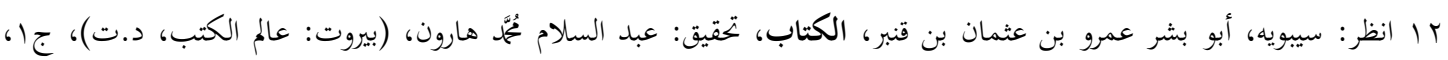

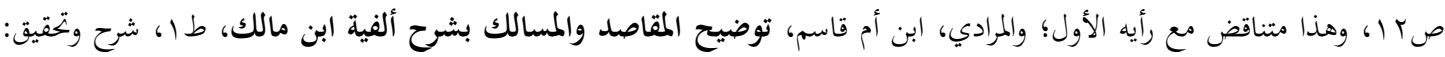

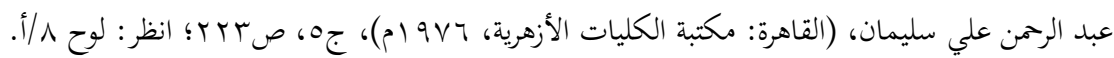

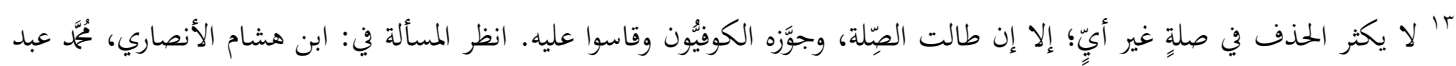

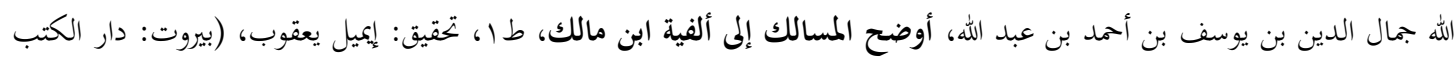

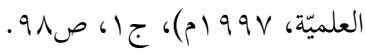

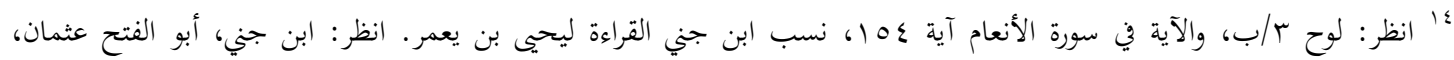

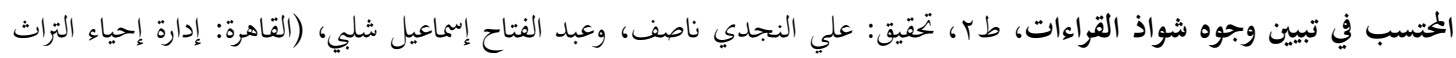

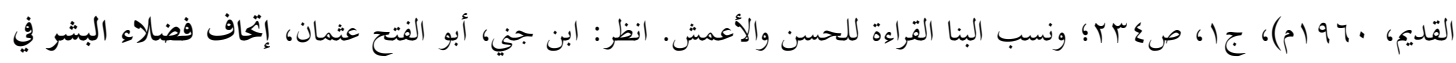

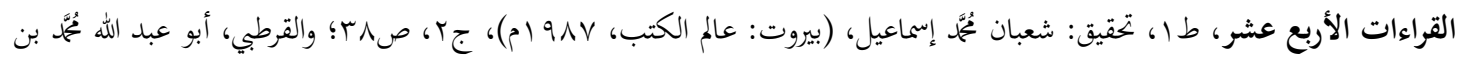

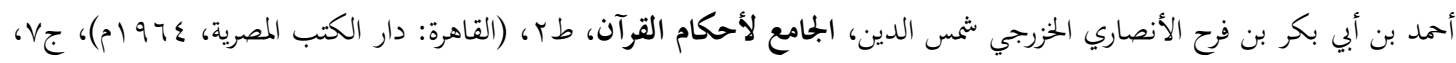

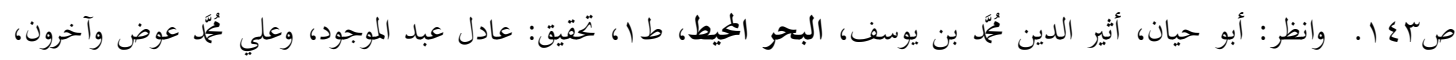

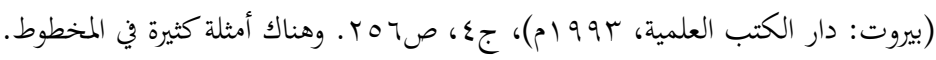

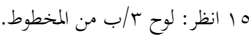

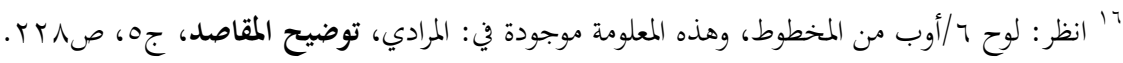

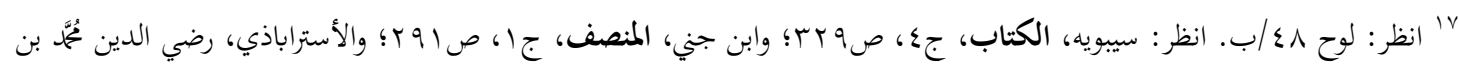

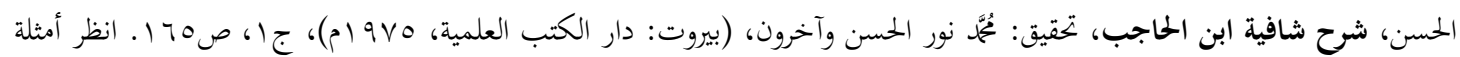

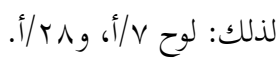

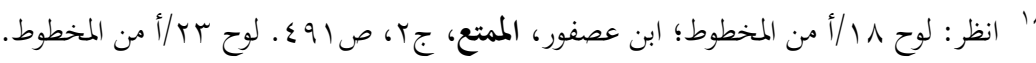

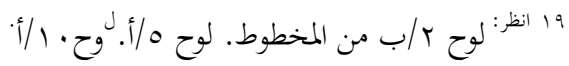

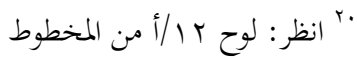

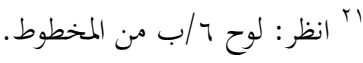

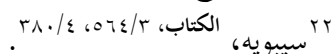

r T بكت عنها في المعاني فلم أجدها. انظر: البلخي، أبو الحسن سعيد بن مسعدة الجاشعي، معاني القرآن، طب، تحقيق: فائز فارس،

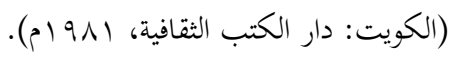

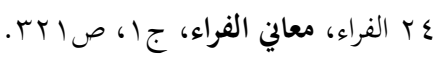

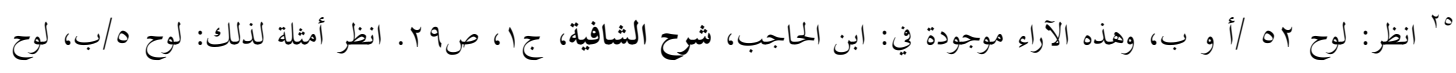

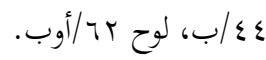

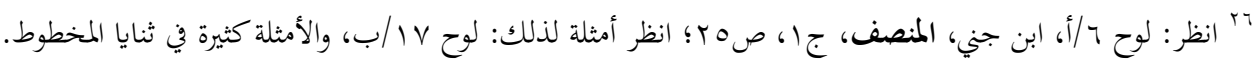

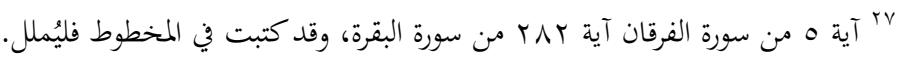


مراجعة كتاب وقراءة نقدية ل: كتاب الدرس الصريف في" شرح السلك والعنوان ومقام الؤلؤة منه والعقيان" المنسوب إلى ابن عصفور

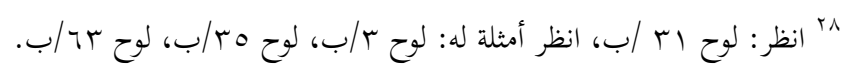

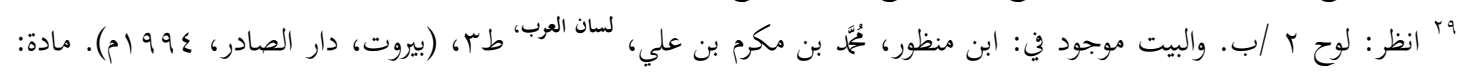

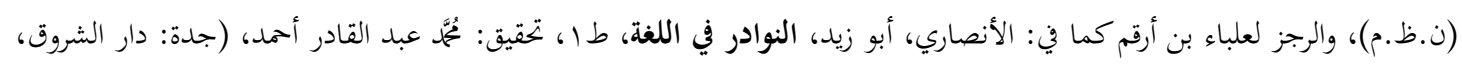

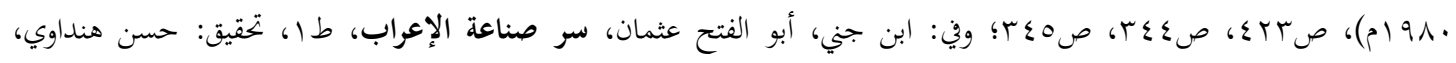

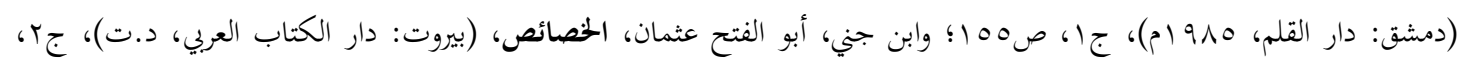

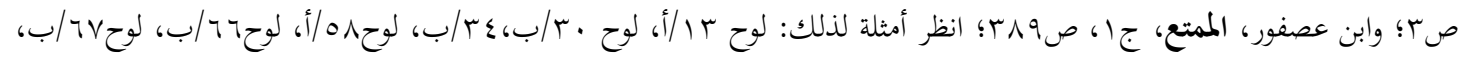

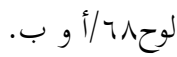

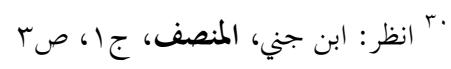

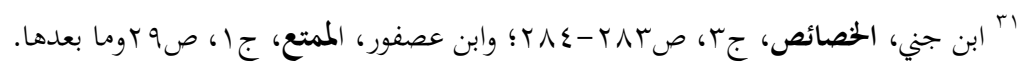

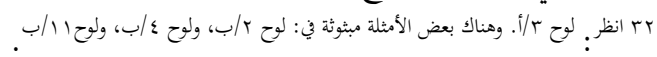

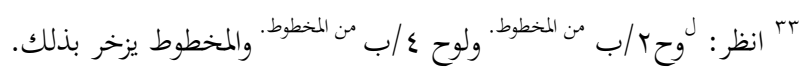

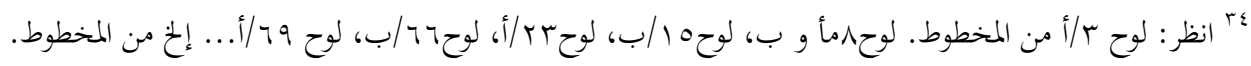

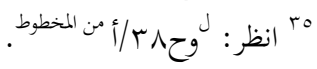

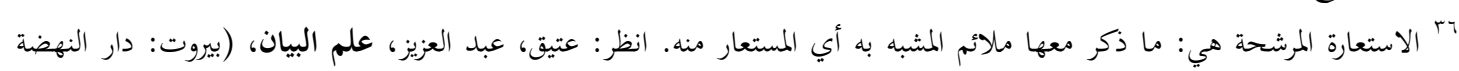

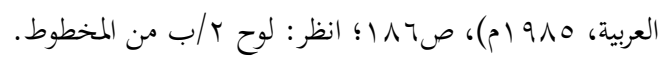

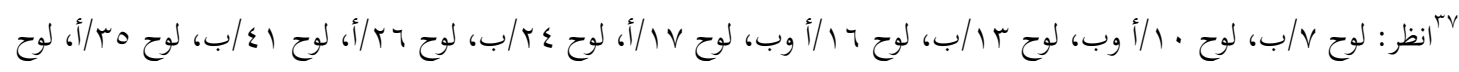

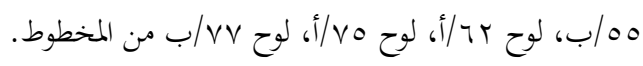

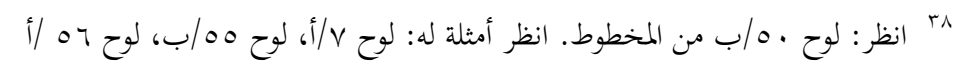

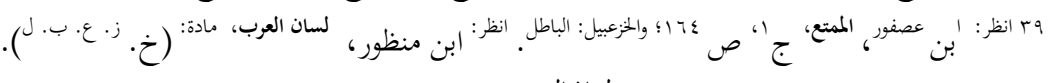

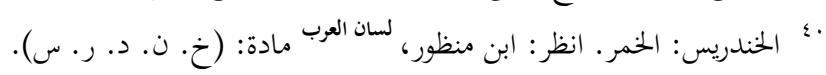

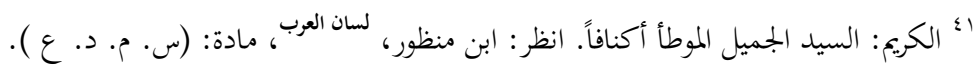

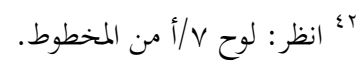

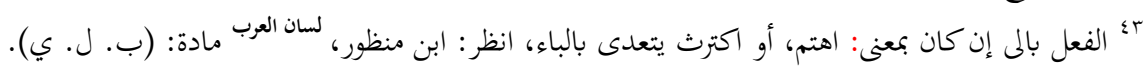

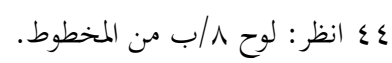

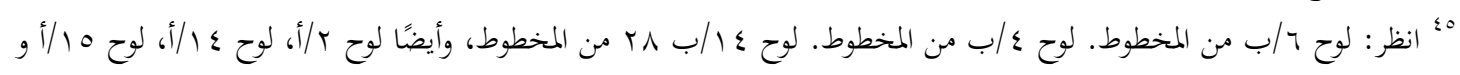
"ج؛ في نسخة ب: وليس كل بدل قلباً، وبها يستقيم الكلام. هنا سقط في الكلام، حيث سقطت ليس، وتمام الكلام هو :(وليس كل بدل

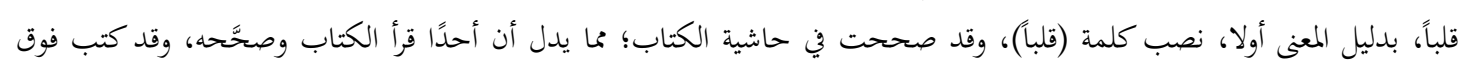
كلمة (ليس) الساقطة كلمة (صح).

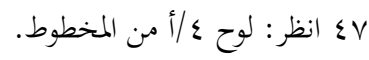

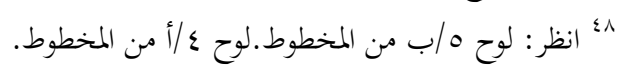

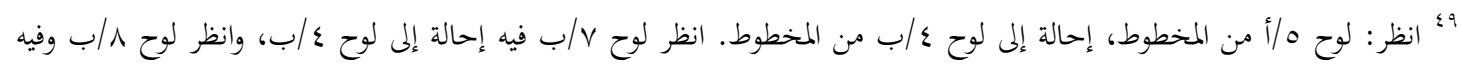

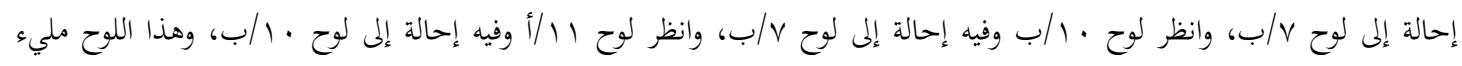

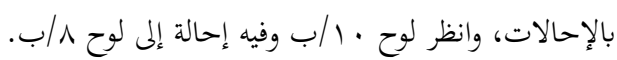

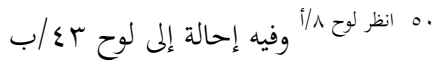

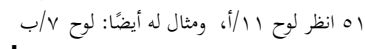




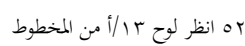

$$
\begin{aligned}
& \text { \& } \\
& \text { ه० انظر: لوح ع /ب، لوح 1/1أ من المخطوط على سبيل المثال. }
\end{aligned}
$$

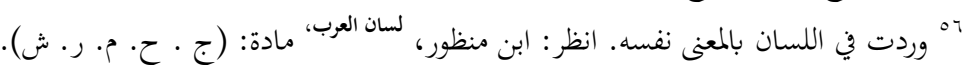

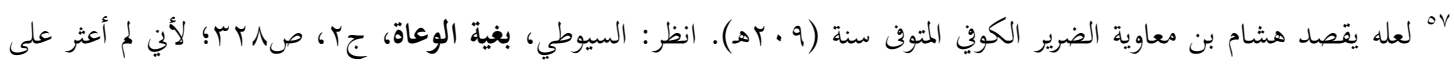

$$
\begin{aligned}
& \text { نغوي معاصر للمرادي أو قريب من عصره هذا الاسم. }
\end{aligned}
$$

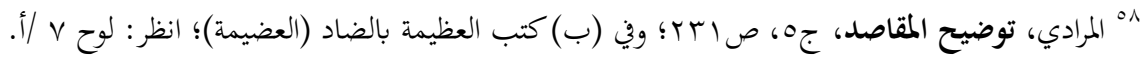

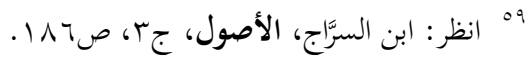

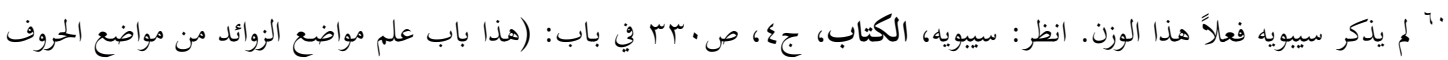

$$
\begin{aligned}
& \text { غير الزوائد). - مان. }
\end{aligned}
$$

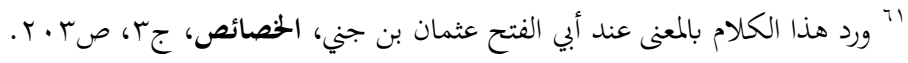

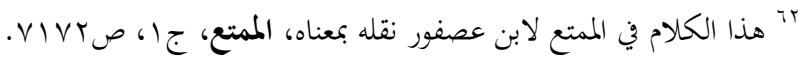

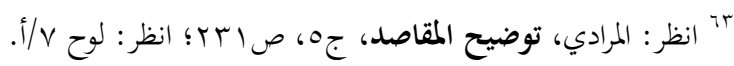

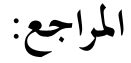

$$
\begin{aligned}
& \text { References: }
\end{aligned}
$$

'abu Haiyān, 'athīr al-Dīn Muhammad Bin Yousif, al-Bạ̣r al-Muḥiț, 1st Tahqīq: 'ādil 'abd al-Mawjūd, wa 'ali Muhammad 'awaḍ wa Edition, Dār al-Kutub al-ilmiyyah, 1993). ’ākharūn, (Beirut:

Al-'anșāri, 'abu Zaid, al-Nawādir Fì al-Lughah, 1st Edition, Tahqīq: Muhammad al-Qādir 'aḥmed, (Jeddah: Dār al-Shurūq, 1980). 'abd

Al-Azharaiy, al-Sheikh khālid Zīn al-Dīn Bin 'abd Allah, al-Tașrīh Bimaḍmūn Tawdịh, 1st Edition, Taḥīq: 'abd al-Fattāḥ Buhīti 'ibrāhīm, (Cairo: al- alLili'lām al-'arabiyy, 1997). zhrā'

Al-Alkhi, 'abu al-Ḥasan Sa'̄id Bin Mas'adah al-Jāshi'iy, Ma'āni al-Qur'ān, $2^{\text {nd }}$

Tahqīq: Fā'iz Fāris, (Kuwait: Dār al-Kutub al-Thaqāfiyyah 1981). Edition, Al-Kutubi, Muhammad Bin Shākir, Fawāt al-Wafiyāt, Taḥīq: 'ị̣sān 'abbās, Dār Șādir, No. date).

(Beirut:

Al-Mubarid, 'abu al-'abbās Muḥammad Bin Yazīd, al-Muqtaḍab, $3^{\text {rd }}$ Edition, Muhammad 'abd al-khāliq 'uḍimah, (Cairo: al-Majlis al-'a'lā Lilsh'ūn Taḥìiq: 'islāmiyyah, 1994). al-

Al-Murādi, Bin Moḥammad Qāsim, Tawụị̄ al-Maqāṣid wa al-Masālik Bisharḥ 'alfiyyah Bin Mālik, 1st Edition, Sharh wa Tahqīq: 'abd al-Raḥmān 'ali

(Cairo: Maktabah al-Kuliyāt al-'zhriyyh, 1976). Sulaimān, Al-Qurțubi, 'abu 'abd Allah Muḥammad Bin 'ahmed Bin 'bi Bakr Bin Farah alal-Khazraji Shams al-Dīn, al-jāmic Li'aḅkām al-Qur'ān, $2^{\text {nd }}$ 'anșāri al-Kutub al-Mașriyyah, 1964). Edition, (Cairo: Dār 
مراجعة كتاب وقراءة نقدية ل: كتاب الدرس الصرفي في" شرح السلك والعنوان ومقام الؤلؤة منه والعقيان" المنسوب إلى

ابن عصفور

Al-Ṣafdi, Șalāh al-Dīn Bin Khlīl Bin 'aibak, al-Wāfi Bilwafiyāt 1st Edition,

Tahquiqu:'aḥmed al-'arnā'ūt wa Turi Muṣtafā, (Beirut: Dār 'ihyā' al-Turāth al'arabiyy, 2000).

Al-Suyūṭi, Jalāl al-Dīn 'abd al-Raḥmān, Bughyah al-Wu'āh Fì Tabqāt alwa al-Nunḥāh, (Beirut: al-Makatabah al-'așriyyah, No. date).Lughawiyyīn

Al-'ustrābādhi, Raḍiy al-Dīn Muhammad Bin al-Hasan, Sharḥ Shāfiyah Bin al-

Tahqiī: Muḥammad Nūr al-Ḥasan wa 'ākharūn, (Beirut: Dār al-Kutub al-Hājib, 'ilmiyyah, 1975).

Al-Zirakli, Khair al-Dīn, al-'alām, $5^{\text {th }}$ Edition, (Beirut: Dār al-'ilm Lilmalayīn, 1980).

Brokulmān, karl, Tārīkh al-'adab al-'arabiyy, 3rd Edition, Nqalahu 'lā al'arabiyyah: Ramḍān 'abd al-Tawāb, wa Rāja'ahā: al-Saiyd Ya'qūb Bakr, (Cairo:

Dār al-Ma'ārif No. date)

Hāji Khalfah, Muṣtafā Bin 'abd Allah, Kashf al-Zunūn 'an 'asāmi al-Kutub wa 'ihyā' al-Turāth al-'arabiyy, No. date). Funūn, (Beirut: Dār alIbn al-Ṭarāwah, 'abu al-Ḥusein Sulaimān Bin Muhammad Bin 'abd Allah Bin

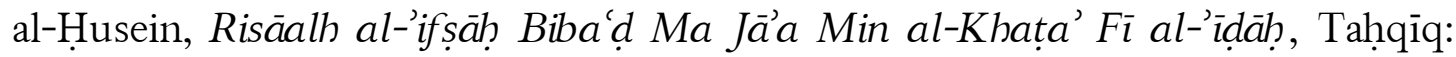
Hātim Șālih al-Ḍāmin, (Cairo: : 'ālm al-Kutub, No. date). Ibn Hishām al-'nșāri, Muhammad 'abd Allah Jamāl al-Dīn Bin Yousif Bin 'abd Allah, 'awḍah al-Masālik 'ilā 'alfiyah Bin Mālik, 1st Edition, 'aḥmed Bin

Ya'qūb, (Beirut: Dār al-Kutub al-'ilmiyyah, 1997). Tahqiì: 'imil

Ibn Jinni, 'abu al-Fath 'uthmān, al-Muḥtasib Fì Tabīn Wujūh Shwādh alQirāāt, $2^{\text {nd }}$ Edition, Taḥqīq: 'ali al-Najdi Naāṣif, wa 'abd al-Fattāh 'ismāê̄l shlby, (Cairo: Dārh 'ihyā' al-Turāth al-Qadīm, 1960). al-Munșif, 1st Edition, Taḥīq: 'ibrāhīm Ibn Jinni, 'abu al-Fath 'uthmān, 'abd Allah 'amīn, (Cairo: 'ihyā' al-Turāth al-Qadīm wa 'iārah al- Mușțaāa wa 'āmmah, 1960). Thaqāfah al-

Ibn Jinni, 'abu al-Fatḥ 'uthmān, al-Khașāiș, (Beirut: Dār al-kitāb al-'arabiyy, date) No.

Ibn Jinni, 'abu al-Fath 'uthmān, Itḥāf Fudalä' al-Bashar Fì al-Qiräàt al-'arba' 1st Edition, Taḥqīq: Sha'bān Muhammad 'ismā'îl, (Beirut: 'ālm al- 'ashar,

Kutub, 1987).

Ibn Jinni, 'abu al-Fatḥ 'uthmān, Sir Șināah al-'írāb, 1st Edition, Tahqiì: Hasan Hindāwi, (Damascuss: Dār al-Qalam, 1985).

Ibn Mu'min, 'ali, al-Mumti' Fì al-Tașrīf, $4^{\text {th }}$ Edition, Tahqīiq: Fakhr al-Dīn

Qabāwh, (Beirut: Dār al-'āfāq al-Jadīdah, 1979).

al-Muqarrab, 1st Edition, Tahqīq: 'ādil 'ahmed 'abd al- Ibn Mu'min, 'ali, 'ali Muḥammad Mu'awwạ̣, (Beirut: Dār al-Kutub al-'ilmiyyah, Mawjūd, wa

1998). 
Ibn Manzūur, Muhammad Bin Mukram Bin 'ali, Lisān al-'arab, $3^{\text {rd }}$ Edition, Șādir, 1994). (Beirut: Dār

'ismāīl Bāshā, Hadiyah al-'ārifin $F \bar{\imath}$ 'smä' al-Mu'allifin wa 'āthār al(Istanbul: Dār 'ihyā̄' al-Turāth al-'arabiyy, 1955). Muṣannifīn, Kahạahah, 'umar Rị̣ā, Mu'jam al-Mu'ailfìn, 1st Edition, (Beirut: Mu'assasah al1973). Risālah,

Sibawaihi, 'abu al-Bishr 'amru Bin 'uthmān Bin Qunbur, al-Kitāb, Taḥqīq: Salām Muhammad Harūn, (Beirut: 'ālam al-Kutub, No. date). 'abd al'utīq, 'abd al-'azīz, 'ilm al-Bayān, (Beirut: Dār al-Nahḍah al-'arabiyyah, 1985). 